\title{
THE IMPACT OF LATE-CAREER HEALTH AND EMPLOYMENT SHOCKS ON SOCIAL SECURITY AND OTHER WEALTH
}

\author{
Richard W. Johnson, Gordon B.T. Mermin, and Dan Murphy* \\ CRR WP 2007-26 \\ Released: December 2007 \\ Draft Submitted: October 2007
}
Center for Retirement Research at Boston College
Hovey House
140 Commonwealth Avenue
Chestnut Hill, MA 02467

Tel: 617-552-1762 Fax: 617-552-0191

http://www.bc.edu/crr

* Richard W. Johnson is a Senior Research Associate at the Urban Institute. Gordon B.T. Mermin is a research associate at the Urban Institute specializing in retirement and aging. Dan Murphy is a research assistant at the Urban Institute. The research reported herein was performed pursuant to a grant from the U.S. Social Security Administration (SSA) funded as part of the Retirement Research Consortium. The opinions and conclusions expressed are solely those of the authors and should not be construed as representing the opinions or policy of SSA, any agency of the Federal Government, the Urban Institute, or Boston College. The authors are grateful to Melissa Favreault, Richard Woodbury, and Sheila Zedlewski for valuable comments.

(C) 2007, by Richard W. Johnson, Gordon B.T. Mermin, and Dan Murphy. All rights reserved. Short sections of text, not to exceed two paragraphs, may be quoted without explicit permission provided that full credit, including () notice, is given to the source. 


\title{
About the Center for Retirement Research
}

The Center for Retirement Research at Boston College, part of a consortium that includes parallel centers at the University of Michigan and the National Bureau of Economic Research, was established in 1998 through a grant from the Social Security Administration. The Center's mission is to produce first-class research and forge a strong link between the academic community and decision makers in the public and private sectors around an issue of critical importance to the nation's future. To achieve this mission, the Center sponsors a wide variety of research projects, transmits new findings to a broad audience, trains new scholars, and broadens access to valuable data sources.

\author{
Center for Retirement Research at Boston College \\ Hovey House \\ 140 Commonwealth Avenue \\ Chestnut Hill, MA 02467 \\ phone: 617-552-1762 fax: 617-552-0191 \\ e-mail: crr@bc.edu \\ www.bc.edu/crr
}

\author{
Affiliated Institutions: \\ American Enterprise Institute \\ The Brookings Institution \\ Center for Strategic and International Studies \\ Massachusetts Institute of Technology \\ Syracuse University \\ Urban Institute
}




\begin{abstract}
Although health and employment shocks are fairly common at older ages and often derail retirement savings plans, Social Security's disability insurance, spouse and survivor benefits, and progressive benefit formula may provide important protections. By contrast, traditional employer-sponsored pension benefits may be especially vulnerable to health and employment shocks immediately before benefit take-up, because pension wealth generally grows rapidly near the end of the career and workers forfeit these increases if they separate early. This study examines the impact of disability onset and job layoffs on Social Security wealth, traditional employer-sponsored pension wealth, and other household wealth for a nationally representative sample of workers age 51 to 55 in 1992.

One-quarter of workers in the sample develop health-related work limitations before age 62 and just more than one-fifth are laid off from their jobs. Regression results show that job layoffs significantly reduce Social Security wealth accumulation, but health shocks increase Social Security wealth, primarily because the system's disability insurance allows some disabled workers to collect benefits before age 62. If Social Security's disability insurance program did not exist, the onset of health-related work limitations would reduce Social Security wealth growth between 1992 and 2004 by about $\$ 3,800$, equal to about 12 percent of the average growth over the period. If spouse and survivor benefits and the progressive benefit formula were also eliminated, the negative impact of health shocks would jump to about $\$ 7,900$, equal to about 19 percent of the average wealth change.
\end{abstract}




\section{Introduction}

Health and employment shocks are fairly common at older ages and often derail retirement savings plans. About 19 percent of adults age 51 to 61 in 1992 were laid off from their jobs at some point before 2002, and about one-third developed serious health problems that limited their work ability over the 10-year period (Johnson, Mermin, and Uccello 2005). People who lose their jobs in the years leading up to retirement or are forced by health problems to reduce their work hours generally have less money available for retirement savings than people who remain at work until their planned retirement age. Job loss between the ages of 51 and 71 reduces household financial and housing wealth by about 33 percent for single people, when other factors are held constant, and the onset of work disability reduces wealth by about 42 percent (Johnson, Mermin, and Uccello 2006). The estimated effects are smaller but still substantial for married people.

Social Security may provide some protection from health and employment shocks at older ages. The system's disability insurance provides some people whose health problems limited their work histories with more generous retirement benefits than they would otherwise receive. Additionally, Social Security allows those with limited earnings to collect benefits based on their current, divorced, or deceased spouse's work history. Various features of the benefit formula, such as the provisions that base benefits on only the highest 35 years of earnings or replace larger shares of pre-retirement lifetime earnings for those with low income than those with high income, also favor those with limited employment histories and lifetime earnings. As a result, health and employment shocks in the years leading up to retirement may have smaller effects on future Social Security benefits than on financial wealth holdings. 
Traditional employer-sponsored pension benefits, however, may be especially vulnerable to health and employment shocks in the years immediately prior to benefit take-up. Most traditional plans tie benefits to years of service and nominal earnings received near the end of the career. As a result, pension wealth tends to grow rapidly in the years just before people qualify for benefits. An additional year on the job increases future benefits not only by adding an additional percentage of pay, but also by raising the value of previous accumulated benefits by a combination of real wage growth and inflation. Thus, many people lose substantial pension wealth if they are laid off from their jobs just before qualifying for benefits or are forced by health problems to retire early.

This paper examines the impact of health and employment shocks on the value of Social Security wealth, traditional employer-sponsored pension wealth, and other household wealth. We begin by measuring the incidence of work disability and job layoffs up to age 62 for a sample of workers age 51 to 55 at study baseline. We then compare wealth levels for those who do and do not experience each type of shock. The final stage of the analysis estimates multivariate models to assess the impact of health and employment shocks on each wealth type and annual Social Security income, holding other factors constant. Simulations measure how well different features of Social Security, such as the progressive benefit formula and the availability of disability benefits and spouse and survivor benefits, protect workers who develop health problems.

The results show that Social Security provides important protections from late-career disability and employment shocks. Disability onset increases Social Security wealth because many people with disabilities are able to collect benefits early. However, work disabilities reduce monthly Social Security payments in old age by forcing people to stop work at relatively young ages, potentially jeopardizing retirement income security. The effects are particularly serious for 
workers with disabilities who do not receive Social Security disability benefits, who make up about three-quarters of those who develop disabilities in their 50s and early 60s. Late-career job layoffs and health problems substantially reduce growth in traditional pension wealth.

\section{Background}

Social Security, employer-sponsored pension benefits, and household savings are key components of retirement income. In 2004, Social Security benefits accounted for nearly twofifths of income for adults age 65 and older, more than half of income for people age 80 and older, and more than four-fifths of income for older people in the bottom two-fifths of the income distribution (Social Security Administration 2006). Employer-sponsored pensions now account for about one-fifth of income at age 65 and older. About 13 percent of income received by older adults comes from assets and about 43 percent comes from earnings (although the importance of earnings declines sharply with age).

These sources of retirement income may be vulnerable to health and employment shocks in the years leading to retirement. Health problems often raise out-of-pocket medical spending (Emanuel et al. 2000; Himmelstein et al. 2005) and force many people to retire early (CBO 2004; McGarry 2004). The increase in health care costs and loss of earnings leave people with less money to save for retirement. Older workers displaced from their jobs often encounter problems finding work (Chan and Stevens 2001), perhaps because employers are reluctant to hire workers near the end of their careers or because older people face outright discrimination in the labor market (Lahey 2005). Because people typically accumulate much of their retirement savings in the decade or so before they stop working (Engen, Gale, and Uccello 1999), adverse health and employment shocks in the 50s and 60s can substantially erode retirement preparedness. 
Health and employment shocks may deal especially harsh blows to pension wealth from traditional defined benefit (DB) plans. Although DB plans have been declining recently as 401(k)-type plans have proliferated and now cover only about one in five wage and salary workers in the private sector (U.S. Bureau of Labor Statistics 2006), they still predominate in the public sector and unionized workplaces. These plans provide workers with lifetime annuities that begin at retirement and pay regular benefits until death. Benefits are typically expressed as a multiple of years of service and earnings received near the end of the career (e.g., 1 percent of average salary received during the final three years on the job times the number of years of service). ${ }^{1}$ Participants cannot collect full benefits until reaching the plan's normal retirement age, but most plans allow workers who retire early to collect reduced benefits if they have enough seniority. Retirement ages vary across plans. The normal retirement age is set at 65 in about twothirds of plans in the private sector, at 62 in about one-sixth of private plans, and at 60 or 55 in most of the rest (U.S. Bureau of Labor Statistics 2005). Most plans set the early retirement age at 55 .

Because future benefits in traditional DB plans rise as workers age and accumulate substantial tenure, typically spiking at the plan's early retirement age and normal retirement age, workers who separate from their employer before they are able to collect benefits often lose significant pension wealth. An additional year on the job increases future pension benefits not only by adding an additional percentage of pay, but also by raising the value of previous accumulated benefits by a combination of real wage growth and inflation. This increment is often substantial for workers with lengthy job tenures. Workers displaced from their jobs before qualifying for benefits or forced by health problems to leave early miss out on these run-ups in

\footnotetext{
${ }^{1}$ Some plans instead pay benefits equal to a fixed dollar amount per service year.
} 
pension wealth, potentially resulting in a substantial loss in future benefits. (Employer-provided disability benefits could partly offset the loss for workers with health problems, however.)

Pension losses from early labor force withdrawal tend to be less serious for workers in 401(k)-type retirement plans, which basically function as tax-advantaged savings accounts to which both employers and employees usually contribute. Contributions cease when workers leave their jobs, so that participants who stop work early typically end up with smaller balances than those who delay retirement, all else equal. However, because account balances grow smoothly while workers are on their jobs employment shocks do not cause workers to miss out on periods of rapid wealth accumulation, as can be the case with DB pensions. Additionally, as long as workers do not withdraw plan funds, existing account balances can continue to earn investment returns after workers separate from their employer, softening the impact of health and employment shocks on future pension benefits.

Although Social Security retirement benefits are based on lifetime earnings, the system is designed to redistribute income to people with low earnings (Steuerle and Bakija 1994), thus potentially providing some protection from health and lay-off shocks that limit employment and earnings. For example, the benefit formula replaces a higher share of earnings for people with low lifetime earnings than high earnings. For people who begin collecting at the normal retirement age, the 2007 formula sets monthly benefits equal to 90 percent of their first $\$ 680$ in average indexed monthly earnings, 32 percent of the next $\$ 3,420$ in indexed monthly earnings, and 15 percent of earnings exceeding $\$ 4,100 .^{2}$ Additionally, only the 35 years of highest

\footnotetext{
${ }^{2}$ People who begin collecting benefits before the normal retirement age, set at age 67 for those born after 1959, will receive smaller payments, and those who delay benefit take-up will receive larger payments. Adults can start collecting retirement benefits as early as age 62 .
} 
earnings figure in the computation of average indexed earnings, so people do not forfeit much Social Security benefits if they are unable to work for more than 35 years.

Spousal and survivor benefits also protect people who experience health and employment shocks that limit their lifetime earnings. Instead of receiving Social Security benefits based on their own earnings history, people have the option to collect benefits based on the earnings history of their current, divorced, or deceased spouses. People who elect benefits from current spouses receive payments equal to half of the spouse's benefit if the current or divorced spouse is alive, or the spouse's full benefit if the spouse is deceased. Spousal and survivor benefits can thus offset the loss of own Social Security retirement benefits, especially for widows and widowers, that can result when health problems and job loss reduce lifetime earnings.

Additionally, Social Security provides disability insurance (DI) benefits to people who develop health problems that render than unable to work. To qualify, people must satisfy Social Security's strict disability criteria, which requires that they have a medically determined disability expected to last at least 12 continuous months (or lead to death) and be unable to engage in "substantial gainful activity." They must also meet Social Security's work history and earnings conditions, which vary by age. Workers who becomes disabled at age 54, for example, must have worked at least eight years. Additionally, disabled workers must demonstrate recent work experience by having worked at least 5 of the 10 years before becoming disabled. Disability benefits, which do not begin for at least five months after disability onset, are based on lifetime earnings, adjusted to account for the relatively short work lives of DI beneficiaries.

Securing DI benefits is often an arduous process, and Social Security denies benefits to many people with disabilities. In 2005, about one-half of DI applicants failed to meet the 
program's medical criteria (Social Security Administration 2007). ${ }^{3}$ However, one recent study concluded that about 60 percent of applicants denied DI benefits actually had disabilities, while about 20 percent of those awarded benefits did not (Benitez-Silva, Buchinsky, and Rust 2004). Further, few rejected applicants work after they are denied DI benefits (Bound 1989; Chen and van der Klaauw forthcoming), suggesting that many are in fact disabled. Award rates vary substantially across states (Social Security Advisory Board 2006), another indication that national, objective criteria do not solely establish disability determinations. The imperfect awards process may undermine the system's ability to protect people who develop health problems and become unable to work.

Previous studies have not resolved questions about how well Social Security protects retirement income for low-income people, including those who develop health problems and lose their jobs late in their careers. There is an ongoing debate about the true progressivity of the system. Although the Social Security benefit formula replaces a higher share of pre-retirement earnings for people with lower lifetime earnings than those with higher lifetime earnings, the system appears less redistributive once workers and their dependents are grouped together, because many people with low lifetime earnings receive benefits based on their spouse's earnings, not their own (Gustman and Steinmeier 2001; Smith, Toder, and Iams 2001). The negative relationship between income and mortality also negates some of the system's redistributive properties (Coronado, Fullerton, and Glass 2000; Liebman 2002). Once Social Security beneficiaries begin collecting, they receive monthly payments until they die. Because life expectancy rises with income (Williams 1990), lower-income people tend to receive fewer monthly payments than higher-income people. However, many of these studies ignore Social

\footnotetext{
${ }^{3}$ Only 35 percent of all 2005 DI applicants were awarded benefits, because Social Security often denied applications for technical reasons, such as failure to satisfy work history requirements (Social Security Administration 2007).
} 
Security's DI benefits, which tend to favor people with lower lifetime earnings. Accounting for DI makes Social Security much more progressive (Cohen, Steuerle and Carasso 2004). This study extends the debate by focusing on how well Social Security protects retirement wealth when workers experience health and employment shocks late in their careers, and comparing the impact of these shocks on Social Security wealth, employer-sponsored DB pension wealth, and other household wealth.

\section{Data and Methods}

Our data come from the Health and Retirement Study (HRS), a longitudinal survey of older Americans conducted by the Survey Research Center at the University of Michigan with primary funding from the National Institute on Aging. The survey collects detailed information on health status, employment, and assets. It oversamples African Americans, Hispanics, and Florida residents but includes sample weights used to adjust the estimates so that they represent the underlying national population. ${ }^{4}$ We examine workers age 51 to 55 in 1992, who were reinterviewed every other year through 2004 (when they were age 63 to 67). After we eliminate respondents who drop out of the survey by 2004 (either through attrition or death) and those who collected Social Security disability benefits in 1992, our full sample consists of 2,829 adults.

To calculate Social Security and pension wealth we use Social Security administrative records and the detailed characteristics of employer-provided pension plans that have been linked to many HRS respondents. ${ }^{5}$ Earnings and benefit records from the Social Security Administration are available for the roughly three-quarters of HRS respondents who authorized the release of their records. These records extend through either 1992 or 2004, depending upon

\footnotetext{
${ }^{4}$ For additional information on the HRS, see Juster and Suzman (1995) or visit http://hrsonline.isr.umich.edu.

${ }^{5}$ These linkages are not available in the public HRS data. Only researchers who have been granted special permission by HRS can gain access to these restricted datasets.
} 
when the respondent gave permission. Because Social Security offers benefits based on a spouse's earnings, the Social Security wealth analysis excludes married respondents whose spouse's administrative earnings records are not available. HRS also obtained detailed pension plan descriptions in 1992 and 1998 from the employers of respondents who provided contact information. Our sample includes 2,120 adults with complete administrative earnings records and 794 adults with DB pension plan information.

\section{Measuring Health and Employment Shocks}

The analysis begins by calculating the incidence of health and employment shocks up to age 62. We ignore shocks that occur at older ages. Because Social Security and most DB plans allow people to collect benefits at age 62 , shocks that occur after age 62 likely only modestly affect public and private pension benefits. We classify adults as experiencing health shocks if they report the onset of health problems that limit the amount or type of work they can do. We

classify adults as experiencing an employment shock if they ever report (by age 62) being laid off from their job since the previous interview.

\section{Calculating Social Security Wealth}

We calculate Social Security wealth in 1992 and 2004 and compare the change over the period for adults who experience shocks and those who do not. We define Social Security wealth at the baseline interview as the expected present value at age 62 of future benefits based on earnings through 1992, assuming that workers take up benefits at age 62. Because the computation is based only on health and employment histories through 1992 when no one in the sample qualifies for DI, it excludes the value of any future Social Security disability benefits. Social Security wealth in 2004 is the present value at age 62 of benefits received through 2004 plus the expected present value of future benefits. The 2004 calculation computes benefits based 
on earnings records through benefit take-up or 2004, and assumes that take up occurs in 2005 for those who have not yet collected benefits. For consistency with the 1992 wealth calculation, 2004 benefit amounts are computed from administrative earnings records (as well as selfreported earnings between 1992 and 2004 for cases in which the administrative records do not extend beyond 1992), not from administrative benefit records or self-reported benefits. In both 1992 and 2004 we also compute benefits for spouses to determine whether respondents qualify for Social Security spouse, divorced spouse, or survivor benefits. ${ }^{6}$ In 2004 we calculate disability benefits based on earnings records for respondents who received disability benefits (according to administrative benefit records or, if not available, self reports). All amounts are expressed in constant 2004 dollars, adjusted by the change in the Consumer Price Index.

Social Security wealth at time $t, S S W_{t}$, can be expressed as

$$
S S W_{t}=\sum_{i=j}^{120} p_{i} \frac{Q_{i} B_{i}+\left(1-Q_{i}\right) S_{i}}{(1+r)^{(i-62)}}
$$

where $t$ is 1992 or 2004, $r$ is the discount rate, $j$ is age at benefit take-up, $p_{i}$ is the probability of surviving from age at time $t$ to age $i, Q_{i}$ is the probability that the spouse is alive when the respondent is age $i$ (conditional on being alive at time $t$ ), $B_{i}$ is the Social Security benefit if the spouse is alive, and $S_{i}$ is the survivor benefit. $B_{i}$ is the maximum of the Social Security benefit based on the respondent's own earnings records and half of the benefit that the spouse earned, at age $i . S_{i}$ is the maximum of the respondent's benefit and the deceased spouse's benefit, at age $i$. Survival probabilities are based on Social Security Administration life tables, and vary by sex and birth cohort. The computations use a real discount rate of 3 percent and assume that no one survives past age 120 .

\footnotetext{
${ }^{6}$ However, we lack information about survivor or divorced spouse benefits for people whose marriages ended before the survey began in 1992.
} 
To examine how various features of Social Security may protect workers from health and employment shocks we also simulate Social Security wealth under the assumption that these features did not exist. We first remove the impact of disability benefits by calculating Social Security benefits for all adults (including those with disabilities) using the retired worker formula and not allowing take-up until age 62 . We then remove spouse and survivor benefits by calculating Social Security wealth based solely on respondent's own earnings records. In those computations, we set

$$
O S S W_{t}=\sum_{i=j}^{120} p_{i} \frac{O B_{i}}{(1+r)^{(i-62)}},
$$

where $\mathrm{OSSW}_{t}$ is own Social Security wealth at time t (1992 or 2004), $O B_{i}$ is the Social Security benefit received at age $i$ based on the respondent's own earnings history, and other variables are as described earlier. Finally, we calculate Social Security wealth based on 40 computation years instead of 35 and on a flat benefit formula that replaces 45 percent of average indexed monthly earnings for all respondents-the mean replacement rate in our sample-instead of the progressive formula used in the actual computations.

We also test the sensitivity of our findings about total Social Security wealth by examining outcomes that better measure economic status in later life. Health and employment shocks encourage people to stop work and take up benefits early, increasing the number of monthly benefits they receive but shrinking each payment. Social Security reduces monthly retirement benefits (but not DI benefits) for those who begin collecting before the normal retirement age, currently set at 66 , to offset the higher number of payments that early claimants receive. For example, adults who begin collecting retirement benefits in 2007 at age 62 , the earliest possible age, receive each month only 75 percent as much as they would have received if they had waited until age 66 to claim benefits. Although Social Security does not reduce DI 
benefits received before the normal retirement age, DI beneficiaries forfeit the chance to earn delayed retirement credits, which increases monthly Social Security payments for those who wait until they have past the normal retirement age to claim benefits. For example, adults age 62 in 2007 can raise their monthly retirement benefits by 32 percent by claiming benefits at age 70 instead of age 66 .

We investigate the impact on later-life outcomes in two ways. First, we compute 2004 Social Security wealth excluding benefits received before age 62, so the measure better reflects benefits received after traditional retirement ages. Second, we compute annual Social Security payments received at the time of benefit take-up, measured in constant 2004 dollars. Social Security's automatic cost-of-living adjustments generally hold the initial annual payment's real value constant over time, so take-up amounts provide a reasonable measure of real Social Security benefits in later life. ${ }^{7}$ As in the wealth calculations, we assume that take-up occurs in 2005 for people who did not yet begin collecting benefits in 2004 (when respondents in the sample range from age 63 to 67$)$.

\section{Calculating Pension Wealth}

The analysis computes DB pension wealth accumulated through 1992 and 2004 for those who experience shocks and those who do not. Pension benefits are estimated from pension plan descriptions, Social Security earnings records, and self-reported hire and quit dates, under the assumption that workers take-up benefits as soon as they are eligible after separating from their employers. ${ }^{8}$ Pension wealth at the first interview is based on earnings through 1992, and 2004

\footnotetext{
${ }^{7}$ However, real monthly Social Security payments sometimes increase when beneficiaries become widowed and receive benefits based on their deceased spouse's earnings instead of their own, or when people receiving disability benefits choose to collect retirement benefits based on their spouse's earnings. Monthly payments also sometimes increase when people work and earn additional Social Security credits after they begin collecting benefits.

${ }^{8}$ The HRS provides a pension benefits calculator that uses summary plan descriptions, job start and end dates, and earnings records. The calculator's default setting estimates pension benefits based on annual earnings in 1992 . However, we run the calculator on Social Security covered earnings records between the job start and end dates.
} 
pension wealth is based on earnings through take-up of benefits. Pension wealth at time $t, P W_{t}$, can be expressed as

$$
P W_{t}=\sum_{i=j}^{120} p_{i} \frac{M_{i}}{(1+r)^{(i-62)}}
$$

where $M_{i}$ is pension benefits received at age $i$ and other variables are as defined earlier.

Estimates are reported in constant 2004 dollars.

Estimated pension wealth does not include benefits from past jobs or jobs that began after 1992. This limitation causes us to understate true pension wealth, especially for workers laid off from their pension job who become re-employed at another pension job. The bias is likely to be modest, however, because workers accumulate most of their DB pension wealth in their 50s, and only 13 percent of respondents in our sample have DB pension coverage from a job that they started after 1992.

\section{Measuring Other Household Wealth}

Finally, we examine how the change over the sample period in all other net household wealth varies by the presence of negative shocks. All other wealth includes the value of housing, bank accounts, stocks, bonds, other real estate, IRAs, vehicles, and businesses, net of mortgage and other debt, expressed in constant 2004 dollars. We divide all other wealth by two for married and partnered respondents to make it comparable with Social Security and pension wealth, which are individual as opposed to household measures.

\section{Modeling Financial Impact of Negative Shocks}

The analysis isolates the effect of health and employment shocks by estimating separate regressions of the change in Social Security, pension, and other household wealth over the period and the change in expected annual Social Security benefits. We use ordinary least squares for the Social Security and pension equations, but median regression for other household wealth because 
it is highly skewed. The regressions include variables indicating the onset of health-related work limitations and layoffs. They also control for race, education, the onset of widowhood and divorce, and certain baseline characteristics, including health-related work limitations, age, martial status, and earnings (measured in constant 2004 dollars). Additionally, we estimate specifications that control for Social Security disability benefit receipt. As noted earlier, relatively few people with disabilities qualify for Social Security disability (Benitez-Silva, Buchinsky, and Rust 2004), and rejected applicants may be especially needy.

\section{Results}

In our full sample, consisting of workers age 51 to 55 in 1992, one-quarter develop health-related work limitations and just more than one-fifth are laid off from their jobs before age 62 (table 1). The incidence of employment and (especially) health shocks declines with educational attainment. Nearly one-third of workers who did not complete high school develop health problems, almost twice the disability rate for college graduates. Workers without high school diplomas are about 28 percent more likely to be laid off than those with college degrees. Women and African Americans are more likely than men and other racial groups to experience health shocks before age 62. For instance, 31 percent of African Americans develop healthrelated work limitations, compared with just one-quarter of non-Hispanic whites. African American workers, however, are less likely to be laid off than other racial groups. Job displacement rates do not vary much by gender or marital status.

The last two columns of table 1 show the incidence of health and employment shocks in the selected samples we use for the Social Security and pension wealth analyses. The incidence of shocks in the Social Security sample is very similar to the full sample, suggesting that restricting the sample to respondents matched to Social Security earnings records does not bias 
Table 1. Incidence of Health and Employment Shocks between 1992 and the Year Respondents Turn 62, Workers Age 51-55 in 1992 (\%)

\begin{tabular}{|c|c|c|c|}
\hline & Full Sample & $\begin{array}{l}\text { Social Security } \\
\text { Sample }\end{array}$ & $\begin{array}{c}\text { DB Pension } \\
\text { Sample }\end{array}$ \\
\hline \multicolumn{4}{|l|}{ Health-Related Work Limitation } \\
\hline All & 25 & 26 & 22 \\
\hline \multicolumn{4}{|l|}{ Gender } \\
\hline Male & 23 & 24 & 21 \\
\hline Female & $27 * *$ & 27 & 23 \\
\hline \multicolumn{4}{|l|}{ Marital Status } \\
\hline Married & 25 & 25 & 21 \\
\hline Single & 27 & 26 & 22 \\
\hline \multicolumn{4}{|l|}{ Education } \\
\hline Not high school graduate & 32 & 32 & 25 \\
\hline High school graduate & $26 * *$ & $26 * *$ & 25 \\
\hline College graduate & $17 * *$ & $17 * *$ & $16 *$ \\
\hline \multicolumn{4}{|l|}{ Race and Ethnicity } \\
\hline Non-Hispanic white & 25 & 25 & 22 \\
\hline African American & $31 * *$ & $34 * *$ & 27 \\
\hline Hispanic & 22 & 21 & 15 \\
\hline \multicolumn{4}{|l|}{ Job Layoff } \\
\hline All & 21 & 22 & 14 \\
\hline \multicolumn{4}{|l|}{ Gender } \\
\hline Male & 21 & 23 & 17 \\
\hline Female & 21 & 21 & $11 * *$ \\
\hline \multicolumn{4}{|l|}{ Marital Status } \\
\hline Married & 20 & 21 & 14 \\
\hline Single & 23 & 24 & 17 \\
\hline \multicolumn{4}{|l|}{ Education } \\
\hline Not high school graduate & 23 & 26 & 17 \\
\hline High school graduate & 21 & $22 *$ & 14 \\
\hline College graduate & $18 * *$ & $17 * *$ & 14 \\
\hline \multicolumn{4}{|l|}{ Race and Ethnicity } \\
\hline Non-Hispanic white & 21 & 22 & 15 \\
\hline African American & $15 * *$ & $16 * *$ & $9 *$ \\
\hline Hispanic & 24 & 22 & 17 \\
\hline Number of Observations & 2,829 & 2,120 & 794 \\
\hline
\end{tabular}

Source: Authors' estimates from the 1992-2004 waves of the Health and Retirement Study.

Note: Asterisks indicate that the percentage for the given category differs significantly from the percentage for the first category in the group $(* p<.10 ; * * p<.05)$. 
our results much. The incidence of shocks in the pension sample, however, is somewhat lower than in the full sample, either because workers in DB plans are less likely to experience these shocks than other workers or because respondents linked to DB plan data differ somewhat from all workers with DB plans.

\section{Impact of Shocks on Social Security Wealth}

Table 2 shows the change in Social Security wealth between 1992 and 2004 for workers who experience health and employment shocks and those who do not. Average Social Security wealth for all workers is about $\$ 130,000$ at baseline (discounted to age 62 and expressed in 2004 dollars), and increases by about $\$ 40,000$ over the period. Most of this growth arises from the additional earnings that workers accumulated between 1992 and 2004. Initial Social Security wealth for workers who never report a health-related work limitation is about $\$ 11,000$ more than

Table 2: Change in Social Security Wealth between 1992 and 2004, by Onset of Health and Employment Shocks, Workers Age 51-55 in 1992

\begin{tabular}{|c|c|c|c|c|c|}
\hline & $\mathbf{N}$ & $\begin{array}{c}\text { Mean Value, } 1992 \\
(\$)\end{array}$ & $\begin{array}{c}\text { Mean Value, } \\
2004(\$)\end{array}$ & $\begin{array}{c}\text { Absolute } \\
\text { Change } \\
(\$) \\
\end{array}$ & $\begin{array}{l}\text { Percent } \\
\text { Change }\end{array}$ \\
\hline All & 2120 & 129,706 & 169,950 & 40,244 & 31.0 \\
\hline \multicolumn{6}{|l|}{ Health-Related Work Limitation } \\
\hline Never & 1419 & 133,806 & 171,314 & 37,508 & 28.0 \\
\hline \multicolumn{6}{|l|}{ Not at Baseline, Onset by Last } \\
\hline Interview & 494 & $122,873 * *$ & 170,321 & 47,448 & 38.6 \\
\hline Limitation at First Interview & 206 & $116,891 * *$ & $159,590 *$ & 42,699 & 36.5 \\
\hline \multicolumn{6}{|l|}{ Job Layoff } \\
\hline Never & 1635 & 128,990 & 169,910 & 40,920 & 31.7 \\
\hline Laid Off by Last Interview & 485 & 132,048 & 170,083 & 38,035 & 28.8 \\
\hline
\end{tabular}

Source: Authors' calculations from the 1992-2004 waves of the Health and Retirement Study.

Notes: All financial amounts are expressed in constant 2004 dollars. Health-related work limitations and job layoffs are restricted to those that occur before age 62. Estimates are weighted to account for the HRS sampling probabilities. Social Security wealth is the expected present value at age 62. Asterisks in the mean value columns indicate that the value for the given category differs significantly from the value for the first category in the group $(* \mathrm{p}<.10 ; * * \mathrm{p}<.05)$. 
for those who develop work limitations by age 62 (but do not report any at baseline) and about $\$ 17,000$ more than for those who report work limitations at baseline. However, average Social Security wealth grows more rapidly over the period, in both absolute and relative terms, for workers who experience health shocks than for those who do not. Baseline Social Security wealth for workers who experience employment shocks is slightly higher than for those who are never laid off, but it grows somewhat more slowly over the period.

The first column of table 3 reports regression results of the change in Social Security wealth under existing law. (The appendix table reports descriptive statistics for the dependent variables and regressors in each model.) After controlling for baseline characteristics and the onset of widowhood and divorce we find that job layoffs significantly reduce Social Security wealth accumulation by about $\$ 4,700$, or 11.9 percent of the average increment. However, health shocks increase Social Security wealth by about $\$ 10,600$ over the period, a 26.6-percent increase above the average growth. The presence of health-related work limitations at baseline also significantly boosts the Social Security wealth growth rate.

The positive impact of health shocks on the accumulation of Social Security wealth may result from features of the system that weaken the connection between lifetime earnings and Social Security wealth. The progressive benefit formula; spouse, survivor, and disability benefits; and the inclusion of only the worker's highest 35 years of earnings in the benefit formula likely reduce the impact of health shocks. Disability benefits are likely to be especially important. Workers who experience health-related work limitations may qualify for disability benefits before reaching retirement age and begin receiving payments based on a formula that does not penalize them for relatively short careers (with limited earnings histories) and does not subject them to actuarial reductions for collecting benefits early. 
Table 3. Coefficients from OLS Regressions of Change in Social Security Wealth Between 1992 and 2004

(with Standard Errors in Parentheses and Coefficients Expressed as Percent of Mean Wealth Change in Brackets)

Alternative Social Security Wealth Scenarios

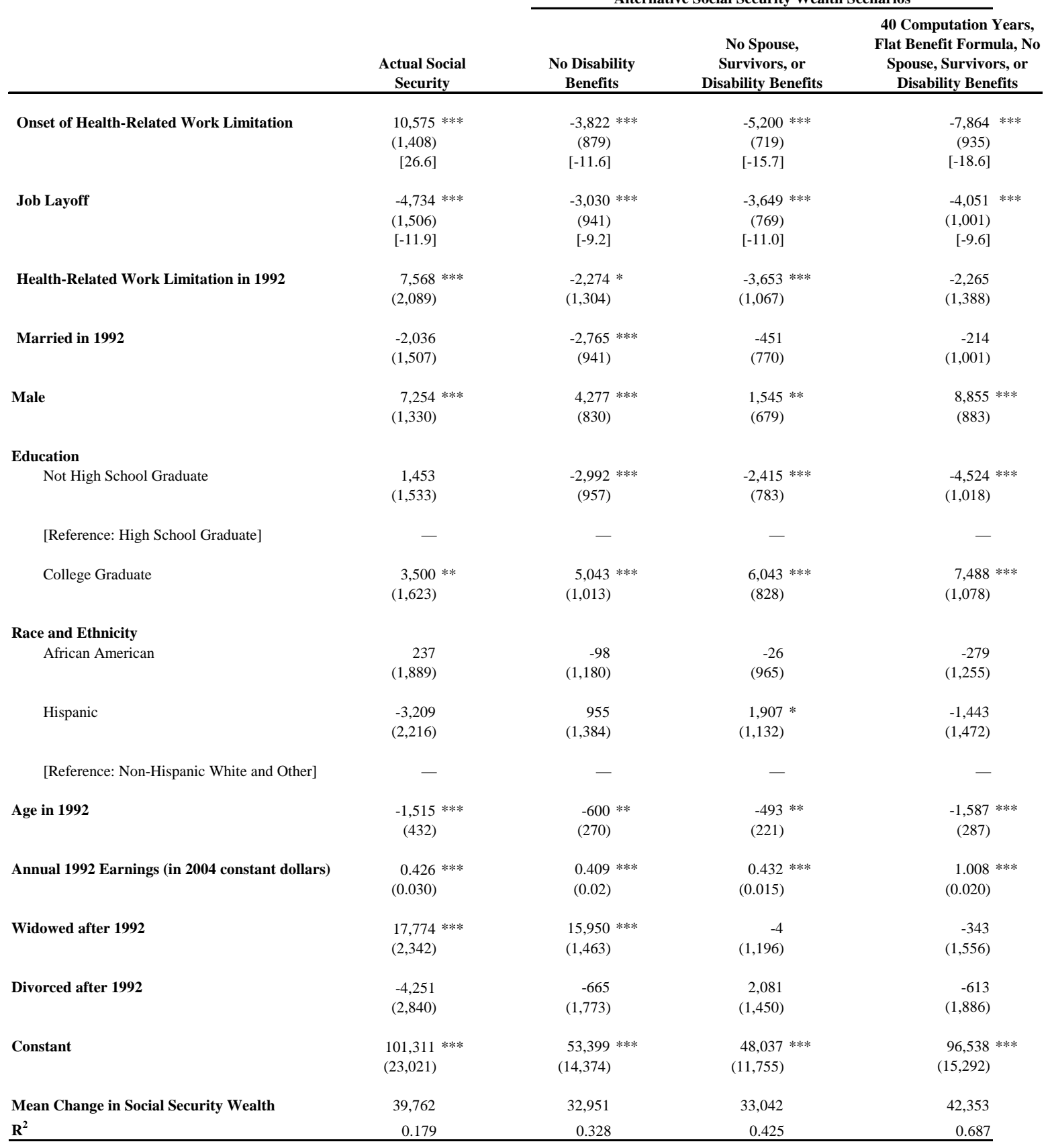

Source: Authors' computations from the 1992-2004 waves of the Health and Retirement Study.

Notes: The sample consists of 2,120 people who in 1992 are working and ages 51 to 55 . Health-related work limitations and job layoffs are restricted to those that occur before

age 62. Social Security wealth is the expected present value at age 62 and is expressed in 2004 real dollars.

$* p<.10 ; * * p<.05 ; * * * p<.01$ 
To examine how well these Social Security features protect workers, we simulate Social Security wealth under three scenarios in which benefits are more directly related to lifetime earnings. The first scenario, reported in the second column of table 3, computes Social Security benefits as if the system's disability component did not exist. Controlling for other factors, we find that the onset of health-related work limitations reduces the growth in Social Security wealth outside of the disability program by about $\$ 3,800$, equal to 11.6 percent of the average growth. Eliminating disability benefits, then, reduces Social Security wealth accumulations by about $\$ 14,400$ for those who develop health problems. Under the second scenario, which assumes that Social Security spouse, survivor, and disability benefits do not exist, the negative impact of health shocks increases to $\$ 5,200$, or 15.7 percent of the average gain in Social Security wealth under this scenario. Finally, when we calculate Social Security wealth without disability, spouse, or survivors benefits using a formula that incorporates the top 40 years of earnings and replaces a constant 45 percent of average indexed earnings for all workers, the negative impact of health shocks jumps to about $\$ 7,900$, equal to 18.6 percent of the average change in wealth.

Stripping these program features from Social Security has smaller effects on the estimated impact of layoffs. We did not expect that eliminating disability benefits would influence the effect of layoffs. Surprisingly, however, we find that eliminating DI reduces layoffs' impact on Social Security wealth by about $\$ 1,700$, although the reduction relative to the average wealth change is modest. Further eliminating survivor and spouse benefits and the progressive benefit formula from Social Security raises the negative effect of job displacement on Social Security wealth by about $\$ 1,000$.

Earnings and demographic characteristics also influence Social Security wealth accumulation. Wealth is positively related to baseline earnings and negatively related to age 
(because older workers have less time to amass additional wealth than younger workers). Men and workers who become widowed also experience relatively rapid growth in Social Security wealth. Men work and earn more in their 50s than women, boosting their wealth holdings. Widowhood increases Social Security wealth by enabling people to collect their deceased spouse's full benefit if it exceeds what they would receive from their own earnings. Most people who become widowed in their 50s are women (Johnson, Mermin, and Uccello 2005), who tend to earn less over their lifetime than men.

\section{Impact on Social Security Payments in Old Age}

Although Social Security—particularly the system's disability insurance component— appears to preserve retirement wealth for people with disabilities, disability onset might reduce monthly benefits at older ages. Many people who develop disabilities respond by leaving the labor force and taking Social Security benefits early (Burkhauser, Couch, and Phillips 1996). Social Security wealth may increase when people qualify for DI because they can collect Social Security for many years, beginning before age 62 . However, their monthly benefits in old age may not be particularly large. Additionally, many people with work disabilities do not collect DI, because they fail the medical screening or they do meet the work history requirements. For example, only 24 percent of respondents with disabilities in our sample receive DI benefits. Workers with disabilities who retire early and collect Social Security early but do not qualify for DI receive lower monthly payments than they otherwise would, because the system reduces retirement benefits for those who collect before the normal retirement age. These actuarial reductions do not necessarily lower Social Security wealth. Instead, they are designed to offset the higher number of payments received by early claimants. Nonetheless, disability onset could jeopardize retirement income security by lowering old-age payments. 
The first column of table 4 partly addresses this possibility by showing regression results of the change in Social Security wealth after excluding wealth derived from benefits received before age 62. After controlling for other factors, we see that post-age-62 Social Security wealth grows significantly faster for workers who develop a health-related work limitation than those who do not, but the difference is only about $\$ 2,500$, much smaller than the advantage in total Social Security wealth accruing to workers with disabilities. About three-quarters of the higher growth in total Social Security wealth that they experience comes from benefits received before age 62. Nonetheless, the onset of work disabilities raises the growth in Social Security wealth after age 62 by about 7 percent. Baseline work disabilities do not significantly affect Social Security wealth accumulations after age 62. Table 4. Coefficients from OLS Regressions of the Change Between 1992 and 2004 in Social Security Wealth
Excluding Benefits Received Before Age 62 and in Annual Social Security Benefits
(with Standard Errors in Parentheses, Coefficients Expressed as Percent of Mean Wealth Change in Brackets)

Onset of Health-Related Work Limitation

Health-Related Work Limitation in 1992

Mean Change in Social Security Wealth or Benefits

$\mathbf{R}^{2}$

Source: Authors' computations from the 1992-2004 waves of the Health and Retirement Study.

Notes: Regressions also control for job layoffs; onset of widowhood and divorce; education; race and ethnicity; gender; and baseline age, marital status, and annual earnings. Health-related work limitations and job layoffs are restricted to those that occur before age 62 . Social Security wealth is the expected present value at age 62. The sample consists of 2,120 people who in 1992 are working and ages 51 to 55 . Annual Social Security benefits are measured at benefit take-up, assumed to occur at age 62 or in 2005 for those who had not yet collected by 2004. Both measures are expressed in 2004 constant dollars.

$* p<.10 ; \quad * * p<.05 ; * * * p<.01$
$-220 * * *$

$-195$

2,385

0.190

$0.284 \quad 0.190$

Change in Expected Annual Social Security Benefits
Wealth, Excluding Benefits

Received Before Age 62 
A more direct way to assess the impact of health shocks on Social Security income in later life is to estimate a regression of initial annual Social Security payments, which generally maintain their real value throughout retirement. The second column of table 4 reports results from this regression. The onset of work disabilities reduces expected annual Social Security benefits by $\$ 220$, or 9.2 percent of the mean change in annual Social Security benefits between 1992 and 2004, after other factors are held constant. These results suggest that people who develop disabilities tend to retire early, limiting their annual Social Security benefits but raising the value of their lifetime benefits.

The impact of health shocks on Social Security wealth may be much more severe for those workers who do not receive DI benefits. About three-quarters of the workers in our sample who report developing health problems that limit the type or amount of work they can perform do not collect any DI benefits. Table 5 shows results from regressions of the change in total Social Security wealth and the change in expected annual Social Security benefits between 1992 and 2004 that control for the receipt of DI benefits. Social Security wealth grows by about $\$ 61,700$ for those who develop work limitations but receive DI benefits, about 155 percent of the average increase over the period. ${ }^{9}$ However, the growth in wealth falls by about $\$ 2,400$, or 5.9 percent, for those who develop health problems but never receive DI benefits. Following the same pattern, the onset of work disabilities increases expected annual Social Security benefits by about $\$ 600$ for those who receive DI benefits (after other factors are held constant), but reduces annual benefits growth by about $\$ 400$ for those without DI benefits.

\footnotetext{
${ }^{9}$ The impact equals the sum of the coefficients on the receipt of DI benefits and the onset of a work limitation.
} 
Table 5. Coefficients from OLS Regressions of the Change in Social Security Wealth and Annual Social Security Benefits Between 1992 and 2004 (Standard Errors in Parentheses, Coefficient Expressed as Percent of Mean Change in Brackets)

\begin{tabular}{|c|c|c|}
\hline & $\begin{array}{l}\text { Change in Social } \\
\text { Security Wealth }\end{array}$ & $\begin{array}{c}\text { Change in Expected Annual } \\
\text { Social Security Benefits }\end{array}$ \\
\hline Onset of Health-Related Work Limitation & $\begin{array}{c}-2,353 * * \\
(1,171) \\
{[-5.9]}\end{array}$ & $\begin{array}{l}-424 * * * \\
(96) \\
{[-17.8]}\end{array}$ \\
\hline Receipt of Disability Insurance Benefits & $\begin{array}{l}64,031 * * * \\
(1,802) \\
{[161.0]}\end{array}$ & $\begin{array}{l}1,009 * * * \\
(147) \\
{[42.3]}\end{array}$ \\
\hline Health-Related Work Limitation in 1992 & $\begin{array}{r}-1,368 \\
(1,671)\end{array}$ & $\begin{array}{l}-336 * * * \\
(136)\end{array}$ \\
\hline $\begin{array}{l}\text { Mean Change in Social Security Wealth } \\
\text { Mean Change in Annual Social Security Benefits } \\
\mathbf{R}^{2}\end{array}$ & $\begin{array}{r}39,762 \\
- \\
0.483\end{array}$ & $\begin{array}{r}- \\
2,385 \\
0.208\end{array}$ \\
\hline \multicolumn{3}{|c|}{$\begin{array}{l}\text { Source: Authors' computations from the } 1992-2004 \text { waves of the Health and Retirement Study. } \\
\text { Notes: Regressions also control for job layoffs; onset of widowhood and divorce; education; race and ethnicity; gender; and baseline age, marita } \\
\text { status, and annual earnings. Health-related work limitations and job layoffs are restricted to those that occur before age } 62 \text {. Social Security } \\
\text { wealth is the expected present value at age } 62 \text {. Annual Social Security benefits are measured at benefit take-up, assumed to occur at age } 62 \text { in } \\
1992 \text { and in } 2005 \text { for the } 2004 \text { computation for those who had not yet collected. Both measures are expressed in } 2004 \text { constant dollars. The } \\
\text { sample consists of } 2,120 \text { people who in } 1992 \text { are working and ages } 51 \text { to } 55 \text {. }\end{array}$} \\
\hline$* p<.10 ; \quad * * p<.05 ; \quad * * * p<.01$ & & \\
\hline
\end{tabular}

The erosion in Social Security wealth and benefits associated with disability onset is modest for those who do not receive DI when compared to total Social Security wealth and benefits. By the time workers have reached their early 50s, they have already accumulated about three-quarters of their lifetime Social Security wealth. The average $\$ 2,400$ loss in wealth that we attribute to disability onset after age 50 amounts to only about 1 percent of average total Social Security wealth. Similarly, the $\$ 400$ loss in annual Social Security benefits equals only about 4 percent of the average $\$ 11,300$ annual payment received (or expected) by our sample respondents. 


\section{Impact on Pension and Other Household Wealth}

Health and employment shocks have more serious effects on employer-sponsored pension wealth and other wealth held outside of Social Security. Table 6 shows the change in DB pension wealth and other per capita household wealth between 1992 and 2004 for adults who experience health and employment shocks and those who do not. Overall, mean pension wealth increases from about $\$ 166,000$ to $\$ 246,000$ over the period. Pension wealth is somewhat lower at the baseline interview for those who later experience health shocks during the period but higher for those who are eventually laid off (although none of these differences are statistically significant). Pension wealth grows more slowly over the period in absolute and relative terms for those who experience work disabilities and layoffs. Mean other household wealth increases from about $\$ 172,000$ to $\$ 323,000$ between 1992 and 2004. However, the baseline level and change over the period is more modest for median other household wealth, which increases from about $\$ 79,000$ to $\$ 122,000$. For both mean and median other household wealth, baseline levels and changes are smaller for those who experience health and employment shocks than those who do not.

Table 7 reports regression results of the change in DB pension wealth and other household wealth. Late-career health and employment shocks sharply reduce DB pension wealth. Controlling for other factors, the regressions show that layoffs reduce pension wealth by about $\$ 29,900$, or 37.1 percent of the average growth in pension wealth over the period (and 12 percent of average total pension wealth). The onset of work disabilities reduces wealth by about $\$ 17,800$, or 22.2 percent of the average pension wealth increment over the period (and 7 percent of average total pension wealth). DB pension wealth also increases with baseline earnings, and grows significantly more rapidly among college graduates than plan participants with less 
Table 6. Change in Pension Wealth and Other Household Wealth between 1992 and 2004, by Onset of Health and Employment Shocks

\begin{tabular}{|c|c|c|c|c|c|}
\hline & $\mathbf{N}$ & $\begin{array}{c}1992 \text { Value } \\
(\$)\end{array}$ & $\begin{array}{c}2004 \text { Value } \\
(\$)\end{array}$ & $\begin{array}{c}\text { Absolute } \\
\text { Change (\$) }\end{array}$ & $\begin{array}{l}\text { Percent } \\
\text { Change }\end{array}$ \\
\hline \multicolumn{6}{|l|}{ MEAN PENSION WEALTH } \\
\hline All & 794 & 165,657 & 245,769 & 80,111 & 48.4 \\
\hline \multicolumn{6}{|l|}{ Health-Related Work Limitation } \\
\hline Never & 592 & 169,370 & 253,709 & 84,340 & 49.8 \\
\hline $\begin{array}{l}\text { Not at Baseline, Onset by Last } \\
\text { Interview } \\
\text { Limitation at First Interview }\end{array}$ & $\begin{array}{r}156 \\
46\end{array}$ & $\begin{array}{l}156,521 \\
148,488\end{array}$ & $\begin{array}{l}222,113 \\
221,873\end{array}$ & $\begin{array}{l}65,592 \\
73,385\end{array}$ & $\begin{array}{l}41.9 \\
49.4\end{array}$ \\
\hline $\begin{array}{l}\text { Job Layoff } \\
\text { Never } \\
\text { Laid Off by Last Interview }\end{array}$ & $\begin{array}{l}680 \\
114\end{array}$ & $\begin{array}{l}162,903 \\
180,785\end{array}$ & $\begin{array}{l}245,588 \\
246,762\end{array}$ & $\begin{array}{l}82,685 \\
65,977\end{array}$ & $\begin{array}{l}50.8 \\
36.5\end{array}$ \\
\hline \multicolumn{6}{|c|}{ MEAN OTHER HOUSEHOLD WEALTH } \\
\hline All & 2829 & 172,201 & 322,762 & 150,561 & 87.4 \\
\hline \multicolumn{6}{|l|}{ Health-Related Work Limitation } \\
\hline Never & 1878 & 195,077 & 375,203 & 180,127 & 92.3 \\
\hline Not at Baseline, Onset by Last & 649 & $128,323 * *$ & $213,509 * *$ & 85,185 & 66.4 \\
\hline Limitation at First Interview & 300 & $117,584 * *$ & $216,678 * *$ & 99,094 & 84.3 \\
\hline \multicolumn{6}{|l|}{ Job Layoff } \\
\hline Never & 2195 & 186,348 & 354,359 & 168,011 & 90.2 \\
\hline Laid Off by Last Interview & 634 & $124,686 * *$ & $216,639 * *$ & 91,954 & 73.7 \\
\hline \multicolumn{6}{|c|}{ MEDIAN OTHER HOUSEHOLD WEALTH } \\
\hline All & 2829 & 78,926 & 121,500 & 42,574 & 53.9 \\
\hline \multicolumn{6}{|l|}{ Health-Related Work Limitation } \\
\hline Never & 1878 & 88,140 & 149,000 & 60,860 & 69.0 \\
\hline Not at Baseline, Onset by Last & 649 & $61,431 * *$ & $88,100 * *$ & 26,669 & 43.4 \\
\hline Limitation at First Interview & 300 & $59,762 * *$ & $71,500 * *$ & 11,738 & 19.6 \\
\hline \multicolumn{6}{|l|}{ Job Layoff } \\
\hline Never & 2195 & 80,128 & 130,250 & 50,122 & 62.6 \\
\hline Laid Off by Last Interview & 634 & $75,787 * *$ & $105,400 * *$ & 29,613 & 39.1 \\
\hline
\end{tabular}

Source: Authors' estimates from the 1992-2004 waves of the Health and Retirement Study.

Notes: The sample consists of people who are working and age 51 to 55 in 1992. Health-related work limitations and job layoffs are restricted to those that occur before age 62. Estimates are weighted to account for HRS sampling probabilities. Pension wealth is the expected present value at age 62. Household wealth is divided by two for married or partnered respondents. Both pension wealth and other household wealth are expressed in 2004 constant dollars. Asterisks in the value columns indicate that the mean or median for the given category differ significantly from the value for the first category in the group $(* \mathrm{p}<.10 ; * * \mathrm{p}<.05)$. 
education and among African Americans than whites. Pension wealth growth slows as age increases.

Health problems significantly slow the accumulation of household wealth held outside of Social Security and employer-sponsored pensions in the years leading up to retirement. The onset of work disabilities reduces the growth in per capita household assets, excluding Social Security and DB pensions, by about $\$ 9,800$, equal to 31.8 percent of the median increase in wealth between 1992 and 2004 but only 8 percent of the median asset level in 2004. Job layoffs reduce the growth in wealth by about $\$ 4,400$ (equal to 14.2 percent of the median increment), but the effect is not statistically significant. Other household wealth increases with education and baseline earnings. The growth rate is also lower for African Americans and Hispanics than whites.

\section{Conclusions}

Work disabilities in the years leading up to retirement erode DB pension wealth and other non-Social Security wealth, but Social Security's disability benefits provide important protections. Workers who develop health problems that limit employment forfeit nearly onefourth of the increase in DB pension wealth that they would have otherwise realized in their 50s and early 60s, and nearly one-third of other non-Social Security wealth. Because of the presence of disability benefits, however, the onset of work limitations in the years before age 62 actually increases Social Security wealth. If the Social Security system did not include disability insurance, work limitations would substantially reduce Social Security wealth. Social Security's survivor and spouse benefits and progressive benefit formula also protect workers who develop health problems, although their impact is relatively modest. 
Table 7. Coefficients from Regressions of the Change in Pension Wealth and Other Household Wealth Between 1992 and 2004 (with Standard Errors in Parentheses and Coefficients Expressed as Percent of Mean or Median Wealth Change in Brackets)

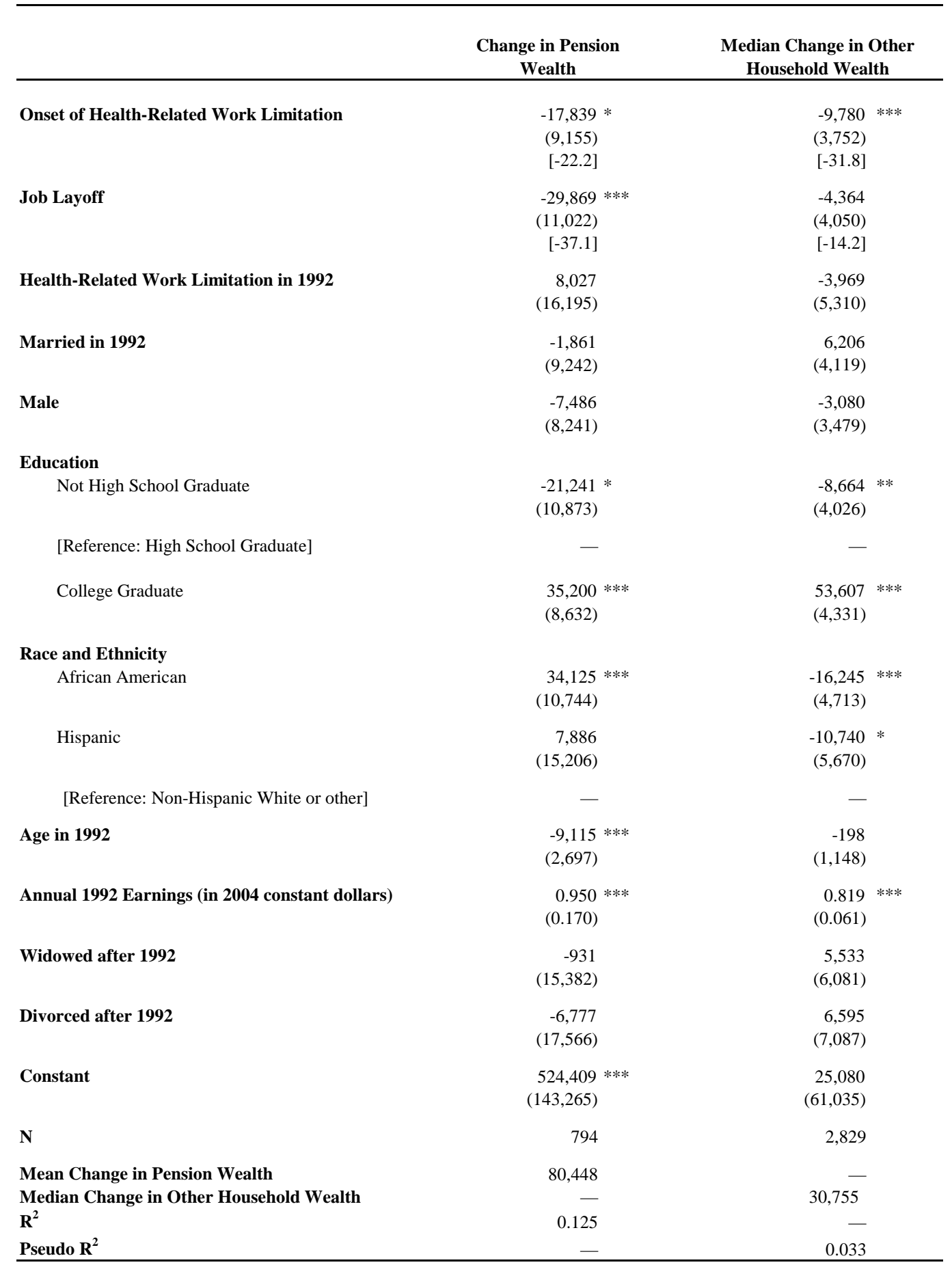

Source: Authors' computations from the 1992-2004 waves of the Health and Retirement Study.

Notes: Estimates of the change in pension wealth are from OLS regression, and estimates of the change in other household wealth are from median regression. The sample is restricted to people who in 1992 are working and ages 51 to 55 . Health-related work limitations and job layoffs are restricted to those those occur before age 62. Pension wealth is the expected present value at age 62. Household wealth is divided by two for married or partnered respondents. Both pension wealth and other household wealth are expressed in 2004 real dollars.

$* p<.10 ; * * p<.05 ; * * * p<.01$ 
Despite the protections offered by Social Security, many people who develop disabilities late in their working lives experience economic hardship in subsequent years. Only 24 percent of the workers in our sample who report developing work limitations go on to collect Social Security DI benefits and reap large gains in Social Security wealth. Most workers who develop health problems lose Social Security wealth, although the losses are relatively modest. Our computations may understate Social Security wealth declines, however, because we assume that people who develop work disabilities live as long (and collect benefits as long) as those who do not develop disabilities. In fact, people who receive DI benefits have much higher mortality rates than other people, although the gap has narrowed recently (Zayatz 2005). Additionally, workers who become disabled experience sharp income declines before age 62 (Congressional Budget Office 2004), even if Social Security wealth rises. And the boost in overall Social Security wealth following disability onset results primarily from early benefit receipt. Instead of having to wait until age 62 to receive Social Security benefits, DI beneficiaries can begin collecting payments as early as five months after disability onset. Monthly Social Security payments in old age are not much higher for DI beneficiaries than for nondisabled people with otherwise similar characteristics. Workers with disabilities who do not collect DI end up with lower monthly benefits, because they tend to retire early and Social Security reduces the monthly payments received by those who collect retirement benefits before the normal retirement age. Finally, of course, people who develop disabilities after age 50-the population we examine in this studymay have better retirement outcomes than people who develop problems at younger ages. About one-half of those awarded DI in 2005 were younger than age 50 (Social Security Administration 2007). 
Layoffs also erode Social Security wealth. However, long-term employment effects appear to be smaller for late career layoffs than work disabilities. For example, after excluding the value of disability insurance benefits, we find that disability onset reduces Social Security wealth more sharply than job layoffs, and layoffs do not significantly erode household wealth held outside of Social Security or employer-sponsored DB plans. Many workers who lose their jobs in their 50s and 60s may eventually find new employment, or their spouses may increase their labor supply to partly offset the loss in family income. Despite the well-known employment challenges faced by displaced workers, especially those nearing retirement (Chan and Stevens 2001; Jacobson, LaLonde, and Sullivan 1993), these results suggest that job layoffs have less serious long-term employment effects than health problems.

In contrast to Social Security, traditional employer-sponsored DB plans severely penalize workers who experience late-career job layoffs or health problems. Workers who are laid off in their 50s and early 60s lose an estimated 37 percent of the pension wealth they would have otherwise accumulated between their early 50s and age 62 . The impact is large because workers laid off in the years immediately before retirement miss out on the large run-up in pension wealth that typically occurs just before workers qualify for benefits. Covered workers who experience health problems lose about 22 percent of the DB pension wealth they would have otherwise accumulated late in their careers.

These results underscore the risks facing workers in traditional DB plans. Many observers lament the steady decline in traditional DB coverage and the growth in 401(k)-type plans that make workers responsible for their own retirement security (e.g., Hacker 2006). To accumulate sizable retirement benefits in a 401(k) plan, for example, workers must generally choose to devote a portion of their paycheck to retirement savings, make sizeable contributions 
throughout their working lives, invest their contributions wisely, and resist the temptation to cash out their accounts if they separate from their employer before retirement. The stock market's vagaries may erode 401(k) balances even for those workers who follow these prudent measures. Traditional DB plans, however, involve other types of risks with potentially serious consequences for retirement security. DB plan participants who leave their employer before retirement—because of health problems, layoffs, employer bankruptcy, or the lure of better opportunities elsewhere-often end up with relatively few benefits.

Although the current Social Security system appears to provide some important protections to people experiencing adverse health and employment shocks late in their careers, the system's growing financial pressures could soon tear the safety net. Disability benefit costs have been soaring recently (Autor and Duggan 2006), and the DI trust fund now pays more in benefits than it receives in taxes. Current projections indicate that the trust fund will be depleted by 2026 (Social Security Board of Trustees 2007). Population aging poses a fiscal challenge to the entire Social Security system, with the combined trust fund expected to be depleted by 2041, according to the latest projections. How policymakers address this fiscal challenge has crucial implications for people who experience late-career health and employment shocks. Efforts to control DI costs by tightening eligibility or cutting benefits could erode protections for workers developing disabilities. Raising Social Security's early entitlement and normal retirement ages could significantly erode retirement security for people unable to remain at work into their mid 60s, especially those who do not qualify for DI. Policymakers must carefully consider how reforms designed to improve Social Security's finances could unravel existing protections for disabled and laid-off workers. 


\section{References}

Autor, David, and Mark Duggan. 2006. "The Growth in the Social Security Disability Rolls: A Fiscal Crisis Unfolding.” NBER Working Paper Series 12436. Cambridge, MA: National Bureau of Economic Research.

Benitez-Silva, Hugo, Moshe Buchinsky, and John Rust. 2004. "How Large Are the Classification Errors in the Social Security Disability Award Process?" NBER Working Paper Series 10219. Cambridge, MA: National Bureau of Economic Research.

Bound, John. 1989. "The Health and Earnings of Rejected Disability Insurance Applicants." American Economic Review 79(3): 482-503.

Burkhauser, Richard V., Kenneth A. Couch, and John W. Phillips. 1996. "Who Takes Early Social Security Benefits: The Economic and Health Characteristics of Early Beneficiaries." The Gerontologist 36(6): 789-99.

Chan, Sewin, and Ann Huff Stevens. 2001. "Job Loss and Employment Patterns of Older Workers.” Journal of Labor Economics 19(2): 484-521.

Chen, Susan, and Wilbert van der Klaauw. Forthcoming. "The Effect of Disability Insurance on Labor Supply of Older Individuals in the 1990s." Journal of Econometrics.

Cohen, Lee, Eugene Steuerle, and Adam Carasso. 2004. "Redistribution under OASDI: How Much and to Whom?" In Strengthening Community: Social Insurance in a Diverse America, edited by Kathleen Buto, Martha Priddy Patterson, William E. Spriggs, and Maya Rockeymoore (103-113). Washington, DC: Brookings Institution Press.

Congressional Budget Office (CBO). 2004. Disability and Retirement : The Early Exit of Baby Boomers from the Labor Force. Washington, DC: Congressional Budget Office.

Coronado, Julia, Don Fullerton, and Thomas Glass. 2000. "The Progressivity of Social Security." NBER Working Paper 7520. Cambridge, MA: National Bureau of Economic Research.

Emanuel, Ezekiel J., Diane L. Fairclough, Julia Slutsman, and Linda L. Emanuel. 2000. "Understanding Economic and Other Burdens of Terminal Illness: The Experience of Patients and Their Caregivers." Annals of Internal Medicine 132(6): 451-59.

Engen, Eric M., William G. Gale, and Cori E. Uccello. 1999. “The Adequacy of Household Saving." Brookings Papers on Economic Activity 1999(2): 65-187.

Gustman, Alan L., and Thomas L. Steinmeier. 2001. "How Effective Is Redistribution Under The Social Security Benefit Formula?" Journal of Public Economics 82(1): 1-28.

Hacker, Jacob S. 2006. The Great Risk Shift. New York: Oxford University Press.

Himmelstein, David U., Elizabeth Warren, Deborah Thorne, and Steffie Woolhandler. 2005. "Illness and Injury as Contributors to Bankruptcy." Health Affairs Web Exclusive W5: 63-73. 
Jacobson, Louis S., Robert J. LaLonde, and Daniel G. Sullivan. 1993. "Earnings Losses of Displaced Workers. ” American Economic Review 83(4): 685-709.

Johnson, Richard W., Gordon B. T. Mermin, and Cori E. Uccello. 2005. "When the Nest Egg Cracks: Financial Consequences of Health Problems, Marital Status Changes, and Job Layoffs at Older Ages." CRR Working Paper No. 2005-18. Chestnut Hill, MA: Center for Retirement Research at Boston College. http://www.bc.edu/centers/crr/papers/wp_2005-18.html.

—. 2006. "How Secure Are Retirement Nest Eggs?" Issue in Brief No. 45. Chestnut Hill, MA: Center for Retirement Research at Boston College. Available at http://www.bc.edu/centers/crr/ib_45.shtml.

Juster, F. Thomas, and Richard Suzman. 1995. "An Overview of the Health and Retirement Study." Journal of Human Resources 30 (supplement): S7-56.

Lahey, Joanna. 2005. “Age, Women, and Hiring: An Experimental Study.” NBER Working Paper No. 11435. Cambridge, MA: National Bureau of Economic Research.

Liebman, Jeffrey B. 2002. "Redistribution in the Current U.S. Social Security System." In The Distributional Aspects of Social Security and Social Security Reform, edited by Martin Feldstein and Jeffrey B. Liebman (11-48). Chicago: University of Chicago Press.

McGarry, Kathleen. 2004. "Health and Retirement: Do Changes in Health Affect Retirement Expectations?" Journal of Human Resources 39(3): 624-48.

Smith, Karen, Eric Toder, and Howard Iams. 2001. "Lifetime Distributional Effects of Social Security Retirement Benefits.” Washington, DC: The Urban Institute.

Social Security Administration. 2006. Income of the Population 55 or Older, 2004. Washington, DC: Social Security Administration.

Social Security Administration. 2007. Annual Statistical Report on the Social Security Disability Insurance Program, 2006. Washington, DC: Social Security Administration.

Social Security Advisory Board. 2006. Disability Decision Making: Data and Materials. Washington, DC: Social Security Advisory Board.

Social Security Board of Trustees. 2007. The 2007 Annual Report of the Board of Trustees of the Federal Old-Age and Survivors Insurance and Federal Disability Insurance Trust Funds. Washington, DC: Board of Trustees, Federal Old-Age and Survivors Insurance and Federal Disability Insurance Trust Funds.

Steuerle, C. Eugene and Jon Bakija. 1994. Retooling Social Security for the 21st Century: Right and Wrong Approaches to Reform. Washington, DC: Urban Institute Press. 
U.S. Bureau of Labor Statistics. 2005. National Compensation Survey: Employee Benefits in Private Industry in the United States, March 2004. Washington, DC: U.S. Department of Labor.

—. 2006. "Employee Benefits Survey.” http://data.bls.gov/cgi-bin/dsrv.

Williams, David R. 1990. "Socioeconomic Differentials in Health: A Review and Redirection." Social Psychology Quarterly 53(2): 81-99.

Zayatz, Tim. 2005. Social Security Disability Insurance Program Worker Experience. Actuarial Study No. 118. Baltimore: Social Security Administration, Office of the Actuary. 
Appendix Table. Descriptive Statistics for Regression Variables

\begin{tabular}{|c|c|c|c|}
\hline & $\begin{array}{l}\text { Change in Social } \\
\text { Security Wealth } \\
\text { (OLS Regression) } \\
\end{array}$ & $\begin{array}{c}\text { Change in } \\
\text { Pension Wealth } \\
\text { (OLS Regression) } \\
\end{array}$ & $\begin{array}{c}\text { Change in Other } \\
\text { Household Wealth } \\
\text { (Median Regression) }\end{array}$ \\
\hline Mean Change in Social Security Wealth $\mathbf{( \$ 2 0 0 4 )}$ & 39,762 & - & - \\
\hline Mean Change in DB Pension Wealth $\mathbf{( \$ 2 0 0 4 )}$ & - & 80,448 & - \\
\hline Mean Change in Other Household Wealth $\mathbf{( \$ 2 0 0 4 )}$ & - & - & 123,604 \\
\hline Median Change in Other Household Wealth $\mathbf{( \$ 2 0 0 4 )}$ & - & - & 30,755 \\
\hline \multicolumn{4}{|l|}{ Mean } \\
\hline Onset of Health-Related Work Limitation & 0.26 & 0.22 & 0.26 \\
\hline DI Onset & 0.09 & - & - \\
\hline Laid Off & 0.14 & 0.13 & 0.14 \\
\hline Health-Related Work Limitation in 1992 & 0.10 & 0.06 & 0.11 \\
\hline Married in 1992 & 0.77 & 0.77 & 0.79 \\
\hline Male & 0.49 & 0.54 & 0.51 \\
\hline \multicolumn{4}{|l|}{ Education } \\
\hline Not High School Graduate & 0.26 & 0.16 & 0.27 \\
\hline College Graduate & 0.21 & 0.32 & 0.21 \\
\hline \multicolumn{4}{|l|}{ Race and Ethnicity } \\
\hline African American & 0.13 & 0.16 & 0.15 \\
\hline Hispanic & 0.09 & 0.07 & 0.10 \\
\hline Age in 1992 & 52.93 & 52.80 & 52.93 \\
\hline Annual Earnings in 1992 (\$2004) & 28,375 & 38,945 & 30,091 \\
\hline Widowed after 1992 & 0.08 & 0.07 & 0.08 \\
\hline Divorced after 1992 & 0.05 & 0.05 & 0.06 \\
\hline $\mathbf{N}$ & 2,120 & 794 & 2,829 \\
\hline
\end{tabular}

Source: Authors' tabulations from the 1992-2004 waves of the Health and Retirement Study.

Note: Tabulations are unweighted. 


\section{RECENT WORKING PAPERS FROM THE}

\section{CENTER FOR RETIREMENT RESEARCH AT BOSTON COLLEGE}

The Effect of Economic Conditions on the Employment of Workers Nearing Retirement Age

Till von Wachter, November 2007

The Costs of Owning Employer Stocks: Lessons From Taiwan

Yi-Tsung Lee, Yu-Jane Liu, and Ning Zhu, November 2007

Health Insurance and the Labor Supply Decisions of Older Workers: Evidence from the U.S. Department of Veterans Affairs

Melissa A. Boyle and Joanna N. Lahey, November 2007

Why Are Companies Freezing Their Pensions?

Alicia H. Munnell and Mauricio Soto, November 2007

Capital Income Flows and the Relative Well-Being of America's Aged Population

Barry P. Bosworth, Gary Burtless, and Sarah E. Anders, November 2007

The Role of Governance in Retirement Investments: Evidence from Variable Annuities

Richard Evans and Rudiger Fahlenbrach, October 2007

A New Approach to Raising Social Security's Earliest Eligibility Age

Kelly Haverstick, Margarita Sapozhnikov, Robert Triest, and Natalia Zhivan, October 2007

What Makes Retirees Happier: A Gradual or 'Cold Turkey' Retirement?

Esteban Calvo, Kelly Haverstick, and Steven A. Sass, October 2007

Why Do Married Men Claim Social Security Benefits So Early? Ignorance, Caddishness, or Something Else?

Steven A. Sass, Wei Sun, and Anthony Webb, October 2007

Measurement Error in Earnings Data in the Health and Retirement Study

Jesse Bricker and Gary V. Engelhardt, October 2007

All working papers are available on the Center for Retirement Research website (http://www.bc.edu/crr) and can be requested by e-mail (crr@bc.edu) or phone (617-552-1762). 